\title{
VALIDATION OF DIGITAL DIETARY ASSESSMENT TOOL IN MONITORING PATIENT FOOD INTAKE AT Dr. SARDJITO HOSPITAL YOGYAKARTA
}

\author{
R. Dwi Budiningsari'), Firma Syahrian²) \\ 1)Department of Nutrition, Faculty of Medicine, Public Health, \\ and Nursing, Universitas Gadjah Mada, Yogyakarta \\ 2)Department of Electrical and Informatics Engineering, \\ Vocational School, Universitas Gadjah Mada, Yogyakarta
}

\begin{abstract}
Background: Energy and protein intake are the outcome indicators of inpatient nutritional care. Monitoring patient dietary intake is an important step after nutrition screening and it is one of the minimum nutrition service standards. However, patient meal plates often have been cleared by serving assistants before dietitians can measure patient plate wastes. Previous studies have shown that the digital photography method is significantly associated with food weighing method. Therefore, it is a valid method to monitor patient dietary intake in hospitals. However, this method has never been studied yet in Indonesia. This study aimed to compare Digital Dietary Assessment Tool (DDAT) and direct observation method (Visual Comstock) with the food weighting method in Dr. Sardjito Hospital Yogyakarta.

Subjects and Method: This was a cross-sectional study conducted at the Cardiovascular Ward, Dr. Sardjito Hospital, Yogyakarta, from June to July 2021. A total of 96 patient meal plates of breakfast were observed by four dietitians. The dependent variables were energy and protein, duration in measuring food intake, and dietician satisfaction. The independent variable was DDAT or visual Comstock, with food weighting as the gold standard. The data were analyzed by paired t-test. Dietician satisfaction was measured by questionnaire.

Results: There was no statistical difference $(\mathrm{p}=0.890)$ in measuring energy between DDAT (Mean= 345.0; $\mathrm{SD}=163)$ and food weighting (Mean=347.6; $\mathrm{SD}=158)$. There was also no statistical difference $(\mathrm{p}=0.890)$ in measuring protein between DDAT (Mean=15.2; $\mathrm{SD}=5.4$ ) and food weighting (Mean= 15.6; $\mathrm{SD}=5.6$ ). The duration in measuring food intake by DDAT (Mean= 37.83; $\mathrm{SD}=15.16$ second) was shorter than visual Comstock (Mean= 361.8; $\mathrm{SD}=41.86$ second) and it was statistically significant $(\mathrm{p}<0.001)$. The satisfaction of dieticians in measuring food intake by DDAT was significantly higher than visual Comstock $(\mathrm{p}<0.001)$.

Conclusion: DDAT is a valid method in measuring of nutrient intake among hospitalized adult patients. Not only has a shorter duration of measurement, DDAT also has higher satisfaction in measuring food intake than visual Comstock.
\end{abstract}

Keywords: validation, dietary assessment tool, photography method, plate waste, adult patients

\section{Correspondence:}

R. Dwi Budiningsari. Department of Health Nutrition, Faculty of Medicine, Public Health, and Nursing, Universitas Gadjah Mada. Jl. Farmako, Sekip Utara, Yogyakarta 55281. Email: budiningsari@ugm.ac.id. Mobile: +6282119693932 